\title{
Digital Media Framing of the Egyptian Arab Spring: Comparing Al Jazeera, BBC and China Daily
}

\author{
Minos-Athanasios Karyotakis ${ }^{1}$, Nikos Panagiotou ${ }^{1}$, Nikos Antonopoulos ${ }^{2}$, Matina Kiourexidou ${ }^{3}$ \\ ${ }^{1}$ School of Journalism and Mass Communication, Aristotle University of Thessaloniki, Greece \\ ${ }^{2}$ Department of Digital Media and Communication, Technological Educational Institute of Ionian Islands, Argostoli, \\ Greece \\ ${ }^{3}$ Medical School, Aristotle University of Thessaloniki, Greece \\ Correspondence: Minos-Athanasios Karyotakis, School of Journalism and Mass Communication, Aristotle University \\ of Thessaloniki, Greece.
}

Received: September 24, 2017

Accepted: October 11, 2017

Online Published: October 12, 2017

doi:10.11114/smc.v5i2.2664

URL: https://doi.org/10.11114/smc.v5i2.2664

\begin{abstract}
Digital Media organizations had a crucial role on the coverage of the Egyptian 'Arab Spring', but until today the outcomes of the news gathering are debatable in the academic society. This study examines the frames of the English-language websites of Al Jazeera, British Broadcasting Corporation (BBC), and China Daily from 9 to 13 February 2011 because of the termination of Hosni Mubarak's presidency. The sample consists of 92 website articles, which report the Egyptian 'Arab Spring' without considering any video footage in the examined news stories. The particular article examines the frames of each article and categorizes them according to a Knowledge Extraction (KE) tool named 'Open Calais', which is owned by another media organization, Reuters. In this study, China Daily's coverage differs from the former researchers' results regarding the 'Arab Spring' covering. According to the findings, there was a merited coverage on the case of the Egyptian 'Arab Spring' without relying exclusively on the content of the official press agency of the People's Republic of China, Xinhua News Agency, and acted like a western-type news media.
\end{abstract}

Keywords: Egyptian Arab Spring, china daily, Open Calais, news media framing, western-type news media

\section{Introduction}

The role of the 'Arab Spring' was significant for the Arab people, especially for the Egyptians who believed that this revolution could lead them to a more modernized nation. The Egyptian 'Arab Spring' did not happen due to the power or the status of political forces or parties and this is the reason why it cannot be associated with specific political movements. The mechanisms that had been created by the regime were strong and had managed to uproot the opposition. Egypt was experiencing a large and growing gap between the different political parties and the several social movements. The regime had failed to absorb the anger of young people, who hoped for a more prosperous future than this of their parents (El Raggal \& Ezzat, 2015). The existing gaps were being exploited by the youth generation of the country and showed that "smartphone citizen journalism is particularly important in areas where governments successfully controlled the activity of professional journalists" (Duffy, 2011, p. 54). New technologies and social media networking contributed to successfully spread the movement displaying that new media in general have the power to alter the discourse of the public sphere (Spitzberg et al., 2013). Those that possessed mobile phones, which could be connected to the web and to immortalize the events, could report through Facebook, Twitter, and YouTube. This footage was often used by well-known news organizations, including Al Jazeera and the British Broadcasting Corporation (BBC), due to the limitations that had been applied by the Egyptian regime.

In the meantime, the Internet has changed the way individuals access the information and the way they use it (Abad, 2014; Go, You, Jung, \& Shim, 2016). News organizations are trying to find new ways to inform the public and become better than their competitors in order to survive (Antonopoulos, Veglis, Gardikiotis, Kotsakis \& Kalliris, 2015). This struggling amongst the news outlets of the globe became more intense with the expansion of the Chinese media market. Chinese government is spending large sums of money for supporting its media companies (Kalathil, 2017). It was believed that this expansion will not happen so easily due to the fact that the Internet and the Chinese blogosphere 
would have provided opportunities for shaping a more critical generation. However, it seems that this is not happening (Lagerkvist \& Sundqvist, 2013).

In this dynamic context, it is important to see the way of how international news organizations (Al Jazeera, BBC, and China Daily) portraying individuals or events and how they decided to frame one of the most crucial incidents of the Egyptian 'Arab Spring', the fall of President Hosni Mubarak.

\section{Literature Review}

International or world news is a term denoting origin from abroad and is related to a foreign country or a global subject. This category of news derived from the invention and the studying of the theory of international communication. This theory states that international communication is the act of communication that takes place in a global scale (Stevenson, 1992). In the beginning, world news stories were not so highly respected amongst journalists, as media organizations used to focus more on national issues. This tendency was highlighted in 1997 by James Hoge, Jr., the editor of Foreign Affairs that wrote in the Columbia Journalism Review an article with the title "Foreign News: Who Gives a Damn?". In this piece of research, he stated that the coverage of international news had declined with the exception of the coverage of the destruction of the Soviet Union. According to Hoge "a world less threatening to America is less newsy, as the newsweekly editors put it. Or in the more colloquial words of television veteran Reuven Frank, sunshine is a weather report, a raging storm is news" (Zuckerman, 2008, p. 2). However, this trend did not last long thanks to the events that took place a few years later and shook the global community. One of those incidents was the September 11 attacks (9/11) that led the United States of America to begin the Global War on Terrorism (GWOT). The aim of the campaign was to wipe out the danger of international terrorism. Nevertheless, the rise of the developing countries and the new financial crisis alongside with the invention of the Internet and its bulk usage by the audience changed completely the way people consume news stories (Zuckerman, 2008).

The dynamic media landscape has provoked many debates about the future of journalism and as a result a plethora of scholars, researchers and professionals of the field have commented on this new reality. According to the former President of the Associated Press, Thomas Curley, "You may not know us well, or perhaps haven't even heard of us. We don't publish a newspaper or run a TV or radio station; what we do is provide the news to those who do for a world insatiable for information" (Curley, 2007, p. 18). Curley's opinion expresses one of the new forms of covering global events. The majority of the companies of the news industry are relying on the news stories, which are provided by renowned news agencies such as Agence France-Presse (AFP), Associated Press (AP), and Reuters. This practice has become more common due to the extended need of providing stories not only on a daily basis, but all day long. Contemporary media world demands for more beats, investigative reportages, and topics that are connected to the sphere of infotainment alongside with more choices for the consumers and the advertisers (Parker, 2014). In this new landscape the news organizations, which have 24/7 newsrooms, try to be first and to have a continuous flow of information. In achieving these goals, they have to rely largely on the news stories that are provided by other sources. In this way, the low-paid journalists do not need to lose time on writing and reporting. They simply have to copy or alter a little the words of the story in order to maintain a somewhat profitable flow of information (Johnston \& Forde, 2011). Moreover, "Internet and social media are forcing companies to implement owned media" (Baetzgen \& Tropp, 2013, p. $5)$.

Internet and the appearance of social media created even more civil roles for news organizations. Perhaps, this was one of the reasons for their tentative reactions toward the Internet in the first place. In the United Kingdom, the Daily Telegraph was the first national newspaper that launched its online edition in 1994, the Electronic Telegraph. The primary attention of the Telegraph was on commercializing the website of the newspaper in an effort to secure the print edition and not to lose readership through reading the news stories on the website without charge. At this point, it should be mentioned that this financially balanced separation of the offline and online presence remains highly debatable until today, promoting the voices that state that the Internet will eventually kill traditional media. However, for many news organizations there were also other ways of thinking and investing. For example, the Guardian and the $\mathrm{BBC}$ invested a lot of money in their digital presence. Their goal was to attract a significant number of online users. On the contrary, MailOnline was one of the media companies that started to expand its online presence quite late, but achieved in becoming the most visited newspaper website in the United Kingdom (Saltzis, 2012). These approaches reveal the tremendous changes that have occurred in the field of journalism over the last decade and that linked with the declining newspaper circulation and TV audiences (Thurman \& Lupton, 2008). Many media companies transformed into multimedia organizations for the sake of their survival. The new multimedia strategy forces journalism to perform multiple jobs even in the nick of time. The Internet via its new forms of journalism, such as blogging and citizen journalism brought more pressure to the professional journalists as it challenged the notion of the gatekeeping role of journalism (Saltzis, 2012). 
In the case of the incidents that are described as 'Arab Spring' and took place the first half of 2011, there is a huge debate about the role of media companies, the central role of social media in reporting the facts, and how they were exploited by the several actors in order to guide or to disorient the social movement. In the beginning, the majority of the researchers and the media coverage focused on the importance of Facebook, Twitter and the use of mobile phones. The results of those approaches were that the narrative was highlighted and that social media succeeded in mobilizing the young crowd making them to create a democratic movement that could challenge the authoritarian regimes of the Arab world. However, this optimistic narrative was replaced by more skeptical ones. Media can format the political context (Sharadga, 2016) and in this case they were not only the sources of information, but agents of the political unrest as they followed and reported the facts and the events that they wanted providing at the same time different explanations of the uprisings (Galal \& Spielhaus, 2012). For example, Osman and Samei (2012) demonstrated the huge differences between the coverage of two prominent newspapers of Egypt. Al-Ahram, which is owned also by the Egyptian government, tried to halt the revolution and to frame it as a movement orchestrated by foreigners wanting to undermine the Egyptian regime. On the contrary, Al-Shuruq supported the movement via publicizing the actions of the protesters and referring to the dead people of the revolution as martyrs.

In conclusion, the plethora of agendas and narratives for the 'Arab Spring' exposed that one cannot define the outcome of these upheavals precisely. So far, no new radical relations between the regimes and the citizens have appeared.

\section{Methodology}

The 'Arab Spring' news coverage triggered a global debate amongst journalists regarding the importance of verifying the information that is spread by citizens, the need for a more neutral and factual based coverage and covering events with/via brand-new media tools. The most important tools were social media and other digital platforms. For example, there was the use of the platform of bit.ly to shorten the Uniform Resource Locator (URL) links of the news organizations. This action managed to spread the news of 'Arab Spring' to an international audience and to increase the pressure on the Arab regimes, forcing the leaders of the countries to hear the demands of the movements and to make compromises (Aday, Farrell, Lynch, Sides, \& Freelon, 2012). The Egyptian revolution began in 2011, when a large number of citizens started to protest demanding the withdrawal of the President Hosni Mubarak. Mubarak's departure in 11 February 2011 forced the Supreme Council of the Armed Forces to take control of the country until the elections on 24 June 2012, in which Mohamed Morsi El Ayat became the fifth President of Egypt. However, the anti-government protests in June 2013 resulted in the removal of Morsi (3 July 2013) by the General Abdel Fattah el-Sisi who became the next President of Egypt.

The step-down of Hosni Mubarak is one of the most prominent incidents of the Egyptian 'Arab Spring', as it was the first ultimate goal of the protestors. This incident made the Egyptian people believe that they regained the sovereignty of their country, its resources and its fate. Existing research has mainly focused on the role of the media in the uprisings against the regimes of the countries that were affected by the 'Arab Spring'. However, researchers do not possess a lot of information about the 'Arab Spring' coverage by well-known media organizations especially given the fact of the role that global mass media play in the portrayal and understanding of these events.

Al Jazeera news media managed to transform the Arab public sphere by introducing programs, which were criticizing taboo topics. This was not common for the Arab world. Thus, it achieved in hosting some of the most popular talks shows of the region (Ayish, 2005). In January 2001, the Qatari network launched its website, Aljazeera.net. Readers from all over the world were visiting the website in order to inform themselves about the Middle East region (Awad, 2005). The British Broadcasting Corporation (BBC) is a public service broadcaster and is the most influential media (radio and television) broadcaster in the world (Westcott \& Mukherjee, 2011). According to researchers, the coverage and the online presence of Al Jazeera and BBC were significant for spreading the uprisings (Howard \& Hussain; 2013). China Daily is China's biggest English-language newspaper (Chen, 2013). China Daily's content can be found in continents such as Europe, America and Africa (Kalathil, 2017). Because it is one of the most influential medium of the country, this paper through the analysis of China Daily's content during the Egyptian Arab Spring researches its perspective-framing.

The authors of this study has chosen to conduct a comparative framing analysis between a) Al Jazeera, which is one of the largest news organizations in the world with a Pan-Arabic perspective that paved the way for the spread of the 'Arab Spring' (Howard \& Hussain; 2013), b) China Daily, China's biggest English-language newspaper (Chen, 2013) and c) $\mathrm{BBC}$, which is the most influential western news organization in the world (Westcott \& Mukherjee, 2011).

To determine how the three selected media covered the aforementioned period of time, this study used content analysis because it is "the systematic assignment of communication content to categories according to rules, and the analysis of relationships involving those categories using statistical methods" (Riffe, Lacy, \& Fico, 2005, p. 3). The content analysis is used in order to define the 'News Frames' of the news organizations. According to Entman (1993, p. 52) 
"Framing essentially involves selection and salience. To frame is to select some aspects of a perceived reality and make them more salient in a communicating text, in such a way as to promote a particular problem definition, causal interpretation, moral evaluation, and/or treatment recommendation for the item described [...] Frames, then, define problems - determine what a causal agent is doing with what costs and benefits, usually measured in terms of common cultural values, diagnose causes - identify the forces creating the problem; make moral judgments - evaluate causal agents and their effects; and suggest remedies - offer and justify treatments for the problems and predict their likely effects". At this point, it should be mentioned that former researches on framing helped in limiting generality and displaying the timelessness of frame theory (e.g. Davis 1995; Bantimaroudis \& Ban, 2001; Gross \& LoBello, 2015). Furthermore, it helped in applying those frames in a variety of topics, such as conflict, human interest, and economic consequence (e.g. Neuman, Just, \& Crigler, 1992; Semetko \& Valkenburg, 2000; Price, Tewksbury, \& Powers, 1997).

This study examines the frames of a sample of 92 articles about the Egyptian 'Arab Spring' and the resignation of the President Hosni Mubarak in the English-language websites of Al Jazeera, BBC, and China Daily from 9 to 13 February 2011. The content of the videos of the examined articles was omitted. In December 2010, the self-immolation of a fruit vendor, Mohamed Bouazizi, triggered a series of demonstrations in Tunisia that were spread throughout Algeria, Jordan, Egypt and Yemen. The causes of the uprising were mostly domestic issues such as, lack of human rights and democracy, corruption, unemployment, food prices, and poverty. The turmoil in each country led to the overthrow of the government and sparked the Syrian civil war. The instability of the regimes of the Arab countries made the regional news coverage quite unsafe for the journalists. That was one of the reasons why the global news agencies relied on the footage, photos, and updates of the local citizens and tried to narrate the 'Arab Spring' stories via the large-scale usage of 'nonprofessional' content.

Articles for this study were taken from the Google search engine for BBC and Al Jazeera and for China Daily from its own website search engine. The articles were located by using separately the keywords "Egypt" and "Hosni Mubarak". All the English-language articles were read and included in the research as long as there was content, which was linked with the Egyptian 'Arab Spring'. The period chosen for the sample was February 9, 2011 through February 13, 2011. The date February 9, 2011 was chosen because it resembles the peaking time of the uprisings that would lead to Mubarak's step-down. The date February 13, 2011 was chosen as the ending date because it was the second day after the resignation of the President of Egypt and it is believed there is a decline in the news coverage. The search results were compared to eliminate any duplication. The total number of articles included in the sample is 92: $24 \mathrm{Al}$ Jazeera English, 29 BBC, and China Daily 39. For the extraction of the frames of each article and their classification, this study used the free online version of 'Open Calais' (http://www.opencalais.com). 'Open Calais' is a Knowledge Extraction (KE) tool "that extracts named entities with sense tags, facts and events. It is available as a web application and as a web service" (Gangemi, 2013, p. 8). Both the output that is marked as 'Social Tags' and 'Topics' decided to be considered as topics, because it is hard to make a distinction between them at a theoretical level. Additionally, 'Open Calais' entails some functions that can help detecting the frames of a story (Gangemi, 2013).

For each article, according to the results of 'Open Calais' the researchers looked for the dominant frames, which reveal the most important aspects of the event that is highlighted by the media organization (Ruigrok \& van Atteveldt, 2007). Researches have shown that the 'Conflict frame' was used during war coverage in order to present the conflict and the hostility amongst different actors, parties, groups and organizations (Neuman et al., 1992). This type of frame was most commonly used by the USA news outlets in the past years (An \& Gower, 2009), but the new researches on the coverage of conflicts provided more dimensions trying to explain further the 'Conflict frame' by locating the angles of the different agents that take part in conflicts. The literature has also spotlighted the kind of coverage that is performed in wars between states, as they produce more coherent news stories that can attract the audience via their dramatic footage and the sensationalism that it evokes. Audience's attraction guarantees the increase of the advertising profits. Here lies the powerful role of journalists that can go beyond the lines and shed light on shady events or even self-censor themselves (Vladisavljević, 2015). Subsequently, the research on the topic of 'Arab Spring' proved that there was some specific category of frames that were used by the news organizations. Bruce (2014) found that Al Jazeera, Al Jazeera English, Al Arabiya, Alhurra, and BBC Arabic included in their coverage a dominant use of the 'Human interest frame'. The latter is one of the most usual frames that can be found in war coverage (Neuman et al. 1992; Semetko \& Valkenburg, 2000) as it helps to sensationalize facts and events. "In crisis situations, the frame stimulates the psychological pulse of people, which ultimately leads them to a more negative attitude toward the crisis showed that the Human interest frame influenced participants' emotional response, and that it was a significant predictor of blame and responsibility in a transgression crisis" (An \& Gower, 2009, p. 108). In 2012, Hamdy and Gomaa also proved that during the Egyptian 'Arab Spring' the posts of the news organizations on social media were using the 'Human interest frame'.

Secondly, there is the 'Public affairs frame', which focuses mostly on political actors or authorities. Benson and Hallin 
(2007) revealed the connection between the flow of information and the influence of politicians. Journalists turn to them to hear their point of view about peculiar events in order to construct the main issues of the future debate. In addition, their comparative analysis of American and French news organizations found that on the aforementioned situations, the US media strongly relied more on the political authorities than the French ones. As far as 'Arab Spring' is concerned, Bruce (2014) proved the findings of Benson \& Hallin (2007), which suggest that in times of unrest the western media outlets tend to rely more on the political authorities. Furthermore, many reporters described the Egyptian 'Arab Spring' as a story of civil unrest. Since the days that it broke out until the resignation of President Hosni Mubarak, this radical movement forced large numbers of citizens out on the streets demanding a more 'democratic' life. It was the first civil unrest story of Egypt that attracted millions of people on the streets (Makhadmeh, 2014). Tierney, Bevc, and Kuligowski in 2006 portray the 'Civil unrest frame' as it is linked with the coverage of natural disasters. In the case of Hurricane Katrina the media outlets based their news stories on sensationalism through publishing footage that represented the behavior of the affected people as normal. Feelings and behaviors such as violence, shock, traumatic experiences, and the fighting for survival were supposed to be typical. The rumors about the on-going procedures of restoring the social breakdown resulted in a coverage, which was heavily based on statements of the affected population. This media approach was quite different from the old ones concerning disaster coverage. As a result, the public believed that the stories of Hurricane Katrina in New Orleans were framed as civil unrest stories.

A significant limitation of this study was that it examined only the three English websites of the following international news organizations: Al Jazeera, BBC, and China Daily. Moreover, the total number of articles included in the sample was collected from a five-day period of time (9-13 February 2011). Examining other English-language websites published in the same or other regions of the world would provide a more complete analysis of the coverage of the Egyptian 'Arab Spring'. This study chose to analyze the content of these news organizations because of their characteristics. Another limitation of this study is that for the extraction of the frames of each article and their classification the free online version of 'Open Calais' was used. Both the output that is marked as 'Social Tags' and 'Topics' were decided to be considered as topics, because it was hard to make a distinction between them at a theoretical level.

Lastly, the researchers read each article to evaluate the Open Calais' output, as it is known that "when researchers rely on computer programs to analyze large volumes of text, they must identify the universe of words that mark the presence of a frame" (Chong \& Druckman, 2007, p. 108). The sample needed to be categorized in columns and checked for duplicates or results that were not linked with the context of the articles. Another key factor in determing the way of the coverage of the three news organizations was to include the author, the sources and the multimedia that were used in each article. Hence, the following research questions were arose:

RQ1: Are there any stories that use the civil unrest frame?

RQ2: Which were the dominant frames of the three news organizations?

RQ3: Do they change over time?

\section{Results}

There were 92 articles included in the sample. Primary focus or dominant frame was assigned to the frames that were the main idea or most prominent in the article as reported by 'Open Calais'. Secondary focus was given to the frames that were present in the article, but were not the dominant frame or focus. The examined articles revealed the following frames: 'Civil unrest', 'Public affairs', 'Human interest', 'Economic' and 'Conflict'. The results show (Figure 1.) that the three news organizations did not focus on all news media frames equally. Al Jazeera, BBC, and China Daily emphasized on the 'Public affairs' (42.39\%), the 'Civil unrest' (41.3\%), and the 'Human interest' (13.04\%) frame. For RQ1 data show that 'Public affairs' $(42.39 \%)$ and 'Civil unrest' $(41.3 \%)$ were represented far more frequently than any of the other frames. 


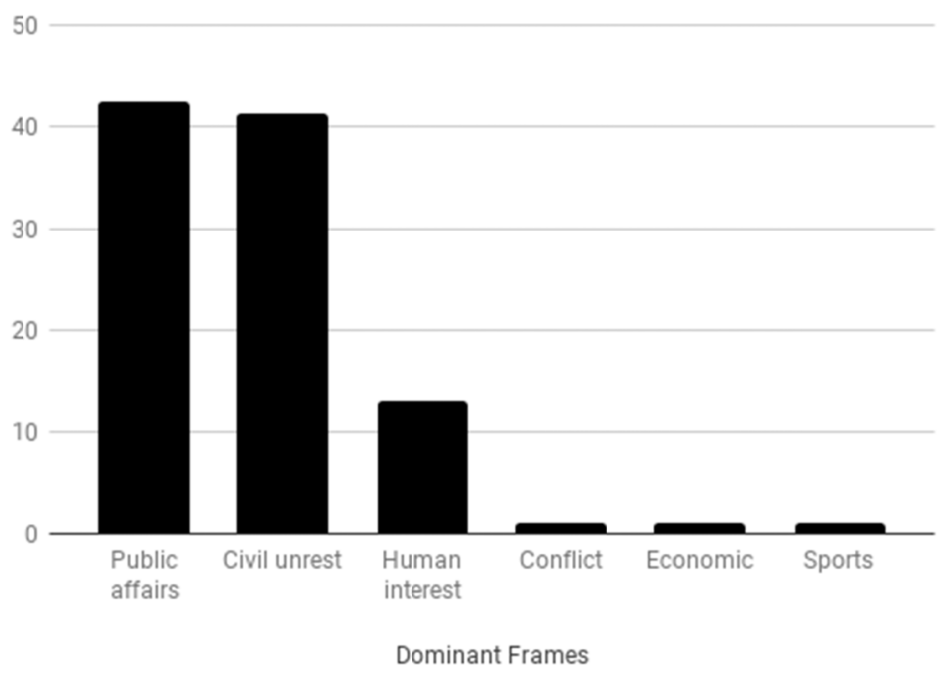

Figure 1. Results of the dominant frames of the digital media (Al Jazeera, BBC \& China Daily) via Open Calais

Additionally, for RQ2 the results show (Figure 2.) the frames that were the main idea or most prominent in the articles for each individual news organizations. For Al Jazeera, the most common frames were the following: 'Civil unrest' (66.6\%), 'Public affairs' (25\%), 'Human interest' (4.16\%), and 'Conflict' $(4.16 \%)$. For the BBC the dominant frames were: 'Public affairs' $(41.37 \%)$, 'Civil unrest' $(34.48 \%)$, and 'Human interest' $(24.13 \%)$. Finally, in the Open Calais' analysis of the articles of China Daily's website there were amongst the most prominent frame stories, an article that could not be categorized, as its context is related to sports (2.56\%). Apart from this fact, the other frames are 'Public affairs' (53.84\%), 'Civil unrest' (30.76\%), 'Human interest' (10.25\%), and 'Economic' (2.56\%).

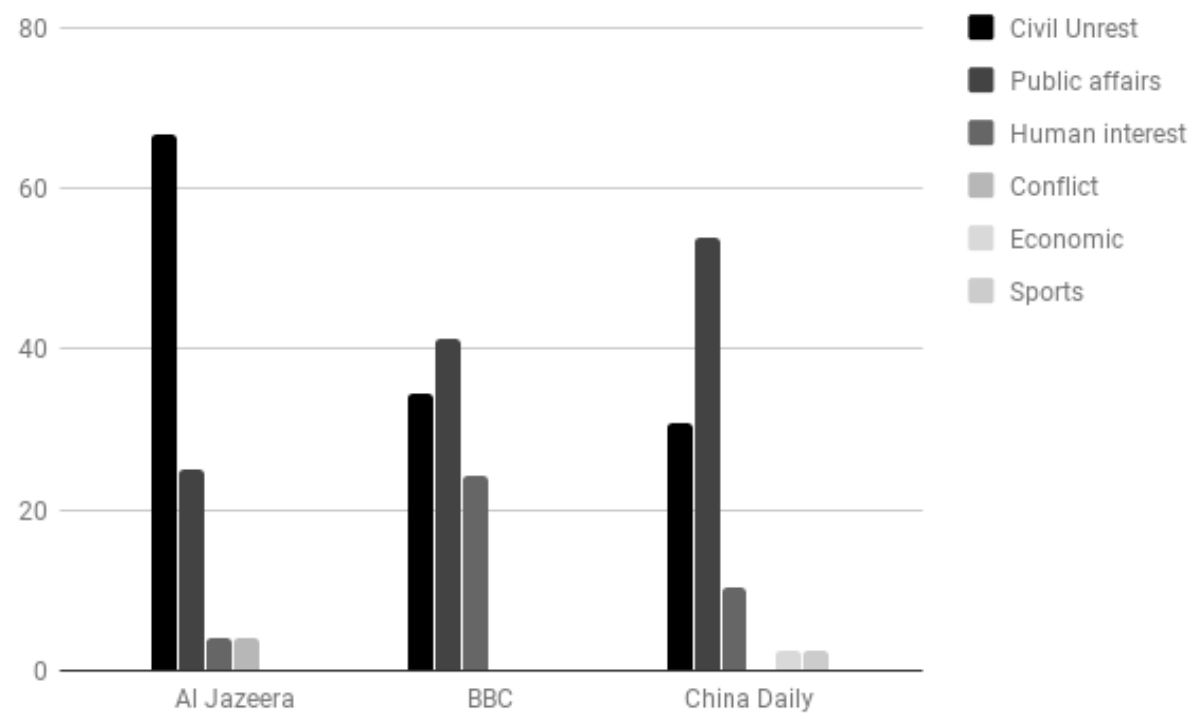

Figure 2. Comparing the dominant frames of the three digital media (Al Jazeera, BBC \& China Daily)

RQ3 addressed whether the frequency of the dominant frames changed during the examined period. On February 9th all the stories of Al Jazeera had the 'Civil unrest frame'. The majority of the published news of the other two media companies were also framed as 'Civil unrest' incidents. The second examined day (02/10/2011) Al Jazeera again relied heavily on the 'Civil unrest frame' alongside with BBC. On the contrary, China Daily's coverage was mainly framed as 'Public affairs' content. On February 11, the Qatari news outlet was once more committed to the same framing. BBC used dominantly the 'Public affairs frame' and the Chinese company was equally divided into three pieces with 'Civil unrest', 'Human interest', and 'Public affairs' framed news. The fourth examined day (02/12/2011) Al Jazeera did not change its coverage filter ('Civil unrest' $60 \%$ ). BBC had the same number of 'Civil unrest', 'Human interest', and 'Public affairs' framed news. In addition, China Daily used more the 'Public affairs framing' (40\%). Lastly, Al Jazeera had a $66.66 \%$ percentage of 'Civil unrest', BBC used a percentage of $40 \%$ for both 'Human interest' and 'Public affairs' framed stories, and the Chinese news organization depended on its 'Public affairs framing' for about $75 \%$.

In addition, Open Calais' analysis detected two articles that have the content of 'hate speech'. The 'Social Tags' of the program labels both of them as Anti-American. The first one, 'Iran's leader to Egypt: Beware of US', which is published 
by China Daily (02/12/2011), includes also content of ‘Anti-Zionism' and 'Antisemitism'. On the contrary, Al Jazeera's news story, 'Iran opposition planning protests', has exclusively 'Anti-American' content, but it is easier to identify its author. It is written by D. Parvaz, who is "senior producer for the Human Rights section at Al Jazeera English, where she commissions pieces and reports extensively on the MENA region and Asia, especially Egypt, Libya and Afghanistan. Her work includes coverage of US Constitutional issues and the earthquake/tsunami/nuclear disasters in Japan. She has been previously based in Tokyo, London and New York". As far as China Daily is concerned, its news story seems to have been written by Mohammad Davari (China Daily), but on the bottom of it, there is the name of the Agence France-Presse. Additionally, China Daily is relied exclusively on other news agencies in order to provide articles for its reader and it does not include articles that were written by correspondents or experts. However, includes more news stories about the examined topic (39/92) than the other two media companies BBC (29/92), and Al Jazeera (24/92), use far more sophisticated types of coverage, and, of course, they have their correspondents on ground collecting footage as well as experiences that can be expressed right on the spot. Videos, interactive maps, photos, and articles from experts of the region theoretically provide a more dynamic coverage. Moreover, the Chinese medium has 27 stories that do not include multimedia content and, on the contrary, all Al Jazeera's news is accompanied with audio, images, video and interactive content. Lastly, BBC has only three stories that do include only text.

\section{Discussion}

Regarding RQ1 Al Jazeera, BBC, and China Daily portrayed the examined days as cases of 'Civil unrest', a term that appeared recently due to the peculiar coverage of Hurricane Katrina, in which feelings and behaviors such as violence, shock, traumatic experiences, and the fighting for survival were supposed to be normal outcomes of the crisis. In addition, according to the findings of Tierney, Bevc, and Kuligowski (2006) the 'Civil unrest frame' reveals that the examined period is portrayed under 'war zone' conditions, treating all the protesters as a unified crowd without paying attention to the cultural background and differences of each individual. As a result, it can be said that the whole movement can easily adopt negative or positive characteristics depending on the narrative of each news organization. Perhaps, the 'Civil unrest framing' coverage is linked to the fact that, according to Makhadmeh (2014), the Egyptian uprising was the first story of civil unrest of Egypt that attracted such millions of people on the streets. The particular study demonstrate that Al Jazeera media website was the only one of these three international news organizations that had as dominant frame the 'Civil unrest' with $66.6 \%$.

China Daily has a dominant frame, which reveals that the Chinese media organization is acting as western-type news media due to the fact that its dominant frame is the 'Public affairs frame' (RQ2). This finding depends on the results of the other researchers of the field (Benson \& Hallin, 2007; Bruce, 2014). Meanwhile, the Chinese news outlet was the only one that contained an economic framed news story. It was believed that this study would provide more of these types of news stories, because "the economic consequences frame reflects a "preoccupation with the 'bottom line,' profit and loss". Focusing on the economic consequences of an issue is a frequently observed strategy for packaging the news and news producers use the consequence frame to make an issue relevant to their audience" (De Vreese, 2004, $p$. 36). According to An and Gower (2009), 'Economic frame' is a common technique in news media framing. BBC's coverage framed the majority of the news stories with the 'Public affairs frame', giving more space to the expression of the political agendas of the actors. This result proves the connection between the flow of information and the influence of politicians, who are recognized in cases of turmoil or festivities as authority. Journalists turn to them to hear their point of view about peculiar events in order to construct the main issues of the future debate (Benson \& Hallin, 2007).

Regarding RQ3 and the frequency of the dominant frames, they did not change during the examined period. Al Jazeera stayed focused on its 'Civil unrest frame', China Daily used predominantly the frame of Public affairs, and BBC was more impartial than the other two media, but relied also a little more on the same dominant frame of the Chinese media organization.

\section{Conclusion}

The new findings revealed that China Daily media website conducted a merited coverage on the case of the Egyptian 'Arab Spring' during the examined five days without relying exclusively on the content of the official press agency of the People's Republic of China, Xinhua News Agency. China Daily published the most news stories (39/92) of the three examined news outlets. As a result, this study shows another perspective of English-language media websites of China that differs from the arguments of Parello-Plesner and Pantucci (2011), as well as the opinion of Olimat (2013). They state that the coverage of the Chinese media organizations was focused almost exclusively on the attempts of helping the citizens of People's Republic of China (PRC). Moreover, it is argued that the Egyptian upheaval did not receive valuable coverage.

Finally, there are numerous additional studies that could be conducted to increase the body of research on the 'Arab Spring', especially for the Chinese news companies, which are believed to play a more vital role in the global agenda 
setting due to their recent expansion. While this study focused mostly on classifying the framings of the news coverage counting the frequency and using statistics to explain what happened, a qualitative analysis would give a more complete and detailed description of the news coverage.

\section{References}

Abad, G. L. (2014). Quality News Websites: International Online Media Evaluation. Larrondo, A., Meso, K., \& Tous, A. (Coords.) Shaping The news Online: A comparative research on international quality media (pp. 63-64). PT: Livros LabCom.

Aday, S., Farrell, H., Lynch, M., Sides, J., \& Freelon, D. (2012). Blogs and Bullets II: New Media and Conflict after the Arab Spring. Peaceworks, 80, 21.

An, S. K., \& Gower, K. K. (2009). How do the news media frame crises? A content analysis of crisis news coverage. Public Relations Review, 35(2), 107-112. https://doi.org/10.1016/j.pubrev.2009.01.010

Antonopoulos, N., Veglis, A., Gardikiotis, A., Kotsakis, R., \& Kalliris, G. (2015). Web Third-person effect in structural aspects of the information on media websites. Journal of Computers in Human Behavior, 44, 48-58. https://doi.org/10.1016/j.chb.2014.11.022

Awad, G. (2005). Aljazeera.net: Identity Choices and the Logic of the Media. In M. Zayani (Ed.), The Al Jazeera Phenomenon: Critical Perspectives on New Arab Media (pp. 80-89). UK: Pluto Press.

Ayish, M. I. (2005). Media Brinkmanship in the Arab World: Al Jazeera's The Opposite Direction as a Fighting Arena. In M. Zayani (Ed.), The Al Jazeera Phenomenon: Critical Perspectives on New Arab Media (pp. 106). UK: Pluto Press.

Baetzgen, A., \& Tropp, J. (2013). Owned Mediall: Developing a Theory from the Buzzword. Studies in Media and Communication, 1(2), 1-10. https://doi.org/10.11114/smc.v1i2.172

Bantimaroudis, P., \& Ban, H. (2001). Covering the crisis in Somalia: Framing choices by the New York Times and the Manchester Guardian. In S. Reese, O. Gandy, \& A. Grant (Eds.), Framing public life: Perspectives on media and our understanding of the social world (pp. 175-184). USA: Erlbaum.

Benson, R., \& Hallin, D. C. (2007). How states, markets and globalization shape the news: The French and American national press, 1965-1997. European Journal of Communication, 22(1), 27-48. https://doi.org/10.1177/0267323107073746

Bruce, M. D. (2014). Framing Arab Spring Conflict: A Visual Analysis of Coverage on Five Transnational Arab News Channels. Journal of Middle East Media, 10, 1-26. https://doi.org/10.12816/0023470

Chen, L. (2013). Could or Should? The Changing Modality of Authority in the China Daily. Journal of the British Association for Chinese Studies, 2, 51-58. ISSN 2048-0601

Chong, D., \& Druckman, J. N. (2007). Framing Theory. Annual Review of Political Science, 10, 103-126. https://doi.org/10.1146/annurev.polisci.10.072805.103054

Curley, T. (2007). Preface. Associated Press (Author). Breaking news: How the Associated Press has covered war, peace and everything else (pp. 18). USA: Princeton Architectural Press.

Davis, J. J. (1995). The effects of message framing on response to environmental communications. Journalism and Mass Communication Quarterly, 72(2), 285-299. https://doi.org/10.1177/107769909507200203

De Vreese, C. H. (2004). The effects of frames in political television news on issue interpretation and frame salience. Journalism and Mass Communication Quarterly, 81(1), 36-52. https://doi.org/10.1177/107769900408100104

Duffy, M. J. (2011). Smartphones in the Arab spring: A revolution in gathering, reporting the news. IPI Report: Media and Money, 53-56.

El Raggal, A., \& Ezzat, H. R. (2015). Egypt: Can a Revolution Be Negotiated?. In I. W. Zartman, (Ed.). Arab Spring: Negotiating in the Shadow of the Intifadat (pp. 85). USA: The University of Georgia Press.

Entman, R. M. (1993). Framing: Toward clarification of a fractured paradigm. Journal of Communication, 43(4), 52. https://doi.org/10.1111/j.1460-2466.1993.tb01304.x

Galal, E., \& Spielhaus, R. (2012). Covering the Arab Spring: Middle East in the Media - the Media in the Middle East. Global Media Journal German Edition, 2(1), 1-6.

Gangemi, A. (2013). A Comparison of Knowledge Extraction Tools for the Semantic Web. The Semantic Web: Semantics and Big Data, 1-15. https://doi.org/10.1007/978-3-642-38288-8 
Go, E., You, K. H., Jung, E., \& Shim, H. (2016). Why do we use different types of websites and assign them different levels of credibility? Structural relations among users' motives, types of websites, information credibility, and trust in the press. Computers in Human Behavior, 54, 231-239. https://doi.org/10.1016/j.chb.2015.07.046

Gross, B., \& LoBello, E. (2015). Color-Coded US Politics: Media Frames Found in US Newspaper Articles from 2004 to 2012. Studies in Media and Communication, 3(2), 84-93. https://doi.org/10.11114/smc.v3i2.1048

Hamdy, N., \& Gomaa, E. H. (2012). Framing the Egyptian uprising in Arabic language newspapers and social media. Journal of Communication, 62(2), 195-211. https://doi.org/10.1111/j.1460-2466.2012.01637.x

Howard, P. N., \& Hussain, M. M. (2013). Democracy's Fourth Wave?: Digital Media and the Arab Spring (pp. 1-131). USA: Oxford University Press.

Johnston, J., \& Forde, S. (2011). The Silent Partner: News Agencies and 21st Century News. International Journal of Communication, 5, 195-197. http://ijoc.org/index.php/ijoc/article/view/928

Kalathil, S. (2017). Beyond the Great Firewall: How China Became a Global Information Power. Center for International Media Assistance, National Endowment for Democracy, 1-41.

Lagerkvist, J., \& Sundqvist, G. (2013). Loyal Dissent in the Chinese Blogosphere: Sina Weibo Discourse on the Chinese Communist Party. Studies in Media and Communication, 1(1), 140-149.

https://doi.org/10.11114/smc.v1i1.121

Makhadmeh, N. (2014). Frames, Modalities, Topics and Sources: A comparative content analysis of natural disaster, terrorist attack and civil unrest crises by Egyptian journalist bloggers and citizen bloggers (Doctoral dissertation, Michigan State University, USA). Retrieved from https://d.lib.msu.edu/etd/3277.

Neuman, W. R., Just, M. R., \& Crigler, A. N. (1992). Common knowledge (pp. 1-22). USA: University of Chicago Press.

Olimat, M. S. (2013). China and the Middle East: From Silk Road to Arab Spring (pp. 89-115). UK: Routledge.

Osman, A., \& Samei, M. A. (2012). The Media and the Making of the 2011 Egyptian Revolution. Global Media Journal German Edition, 2(1), 1-19.

Parello-Plesner, J., \& Pantucci, R. (2011). China's Janus-Faced Response to the Arab Revolutions. ECFR/34, 1-5.

Parker, B. T. (2014). Branding Online News Providers: Brand Personality and the Image Congruence Effect. Studies in Media and Communication, 2(2), 1-10. https://doi.org/10.11114/smc.v2i2.502

Price, V., Tewksbury, D., \& Powers, E. (1997). Switching trains of thought: The impact of news frames on readers' cognitive responses. Communication Research, 24, 481-506. https://doi.org/10.1177/009365097024005002

Riffe, D., Lacy, S., \& Fico, F. (2005). Analyzing Media Messages: using quantitative content analysis in research (pp. 1-22). USA: Lawrence Erlbaum Associates, Inc.

Ruigrok, N., \& van Atteveldt, W. (2007). Global Angling with a Local Angle: How U.S., British, and Dutch Newspapers Frame Global and Local Terrorist Attacks. Press/Politics, 12(1), 68-90.

https://doi.org/10.1177/1081180X06297436

Saltzis, K. (2012). Doing Journalism Online: How UK News Organizations Have Adapted in the Age of the Internet. In E. Siapera, \& A. Veglis (Eds.), The Handbook of Global Online Journalism (pp. 462-475). UK: Blackwell Publishing. https://doi.org/10.1002/9781118313978.ch25

Semetko, H. A., \& Valkenburg, P. M. (2000). Framing European politics: A content analysis of press and television news. Journal of Communication, 50(2), 93-108. https://doi.org/10.1111/j.1460-2466.2000.tb02843.x

Sharadga, T. M. A. (2016). The Media Consumption Patterns of the Arab Spring Revolutions: A Field Study for the students' Perceptions in the faculty of Journalism and Press at Al-yarmouk University. Studies in Media and Communication, 4(2), 99-109. https://doi.org/10.11114/smc.v4i2.1951

Spitzberg, B. H., Tsou, M. H., Dipak, K., Gupta, D. K., An, L., Gawron, J. M., \& Lusher, D. (2013). The Map is Not Which Territory?: Speculating on the Geo-Spatial Diffusion of Ideas in the Arab Spring of 2011. Studies in Media and Communication, 1(1), 101-115. https://doi.org/10.11114/smc.v1i1.64

Stevenson, R. L. (1992). Defining International Communication as a Field. Journalism Quarterly, 69(3), 543-553. https://doi.org/10.1177/107769909206900302

Thurman, N., \& Lupton, B. (2008). Convergence calls: multimedia storytelling at British news websites. Convergence: The International Journal of Research into New Media Technologies, 14(4), 439-455. 
https://doi.org/10.1177/1354856508094662

Tierney, K., Bevc, C., \& Kuligowski, E. (2006). Metaphors matter: disaster myths, media frames, and their consequences in Hurricane Katrina. The Annals of the American Academy of Political and Social Science, 604, 57-81. https://doi.org/10.1177/0002716205285589

Vladisavljević, N. (2015). Media framing of political conflict: A review of the literature. Media, Conflict and Democratisation, 2-31.

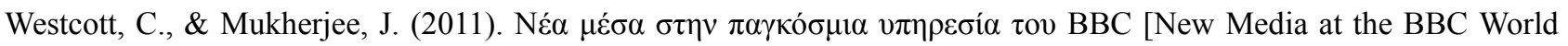

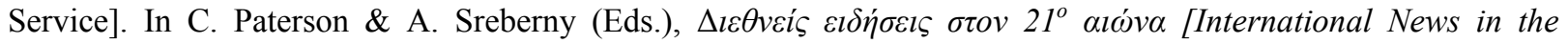
Twenty-First Century] (pp. 167). GR: Sideris Publications.

Zuckerman, E. (2008). International News: Bringing About the Golden Age. Berkman Center for Internet and Society at Harvard University, 2-4.

\section{Copyrights}

Copyright for this article is retained by the author(s), with first publication rights granted to the journal.

This is an open-access article distributed under the terms and conditions of the Creative Commons Attribution license which permits unrestricted use, distribution, and reproduction in any medium, provided the original work is properly cited. 